\title{
Correlation between c-Met and ALDH1 contributes to the survival and tumor-sphere formation of ALDH1 positive breast cancer stem cells and predicts poor clinical outcome in breast cancer
}

\author{
Yuka Nozaki ${ }^{1,5}$, Shoma Tamori ${ }^{1,5}$, Masahiro Inada ${ }^{1}$, Reika Katayama ${ }^{1}$, Hiromi \\ Nakane ${ }^{1}$, Osamu Minamishima ${ }^{1}$, Yuka Onodera ${ }^{1}$, Makoto Abe ${ }^{1}$, Shota Shiina ${ }^{1}$, \\ Kei Tamura ${ }^{1}$, Daichi Kodama ${ }^{1}$, Keiko Sato ${ }^{3}$, Yasushi Hara ${ }^{4}$, Ryo Abe ${ }^{4}$, Ryoko \\ Takasawa ${ }^{2}$, Atsushi Yoshimori ${ }^{6}$, Nariyoshi Shinomiya7, Sei-ichi Tanuma ${ }^{2}$ and \\ Kazunori Akimoto ${ }^{1,5}$ \\ ${ }^{1}$ Department of Medicinal and Life Science, Faculty of Pharmaceutical Sciences, Tokyo University of Science, Chiba, Japan \\ 2 Department of Pharmacy, Faculty of Pharmaceutical Sciences, Tokyo University of Science, Chiba, Japan \\ ${ }^{3}$ Department of Information Sciences, Faculty of Science and Technology, Tokyo University of Science, Chiba, Japan \\ ${ }^{4}$ Research Institute for Biochemical Sciences, Tokyo University of Science, Chiba, Japan \\ ${ }^{5}$ Translational Research Center, Research Institute for Science\& Technology, Tokyo University of Science, Chiba, Japan \\ ${ }^{6}$ Institute for Theoretical Medicine, Inc., Yokohama, Japan \\ ${ }^{7}$ Department of Integrative Physiology and Bio-Nano Medicine, National Defense Medical College, Saitama, Japan \\ Correspondence to: Kazunori Akimoto, email: akimoto@rs.tus.ac.jp
}

Keywords: ALDH1, breast cancer, CSC, C-Met

Received: April 03, $2017 \quad$ Accepted: August 13, 2017

Published: August 22, 2017

Copyright: Nozaki et al. This is an open-access article distributed under the terms of the Creative Commons Attribution License (CC-BY), which permits unrestricted use, distribution, and reproduction in any medium, provided the original author and source are credited.

\section{ABSTRACT}

c-Met is a receptor-type tyrosine kinase, which is involved in a wide range of cellular responses such as proliferation, motility, migration and invasion. It has been reported to be overexpressed in various cancers. However, the role of c-Met in breast cancer stem cells (CSCs) still remains unclear. We herein, show that c-Met expression is significantly elevated in Basal-like type of breast cancer in comparison with other subtypes. High expression of c-Met strongly correlated with the expression of two CSC markers, ALDH1A3 and CD133 in breast cancers. In addition, breast cancers at tumor stage III-IV expressing both $c-M^{\text {het }}{ }^{\text {high }}$ and $A L D H 1 A 3^{\text {high }}$ had poor prognosis. Furthermore, treatment with c-Met inhibitors (Crizotinib, Foretinib, PHA-665752 and Tivantinib) in MDA-MB157 cells with high c-Met protein expression resulted in significant suppression in cell viability, contrary to MDA-MB468 cells with low $c-M e t$ protein expression. These c-Met inhibitors also suppressed cell viability and tumor-sphere formation of ALDH1 ${ }^{\text {high }}$ breast cancer cells with high c-Met expression. These results suggest that c-Met in ALDH1 positive CSCs seems to play an important role in breast cancer repopulation. Therefore, we conclude that c-Met is a potential therapeutic target in ALDH1 positive breast CSCs.

\section{INTRODUCTION}

Breast cancer is one of the most common cancers occurring in women worldwide with 1.7 million new cases (25.2\% of all cancers in women) and 0.5 million-cancer deaths ( $14.7 \%$ of all cancer death in women) according to an estimate from the International Agency for Research on Cancer (IARC) [1]. Breast cancer has been widely classified based on specific gene expression signature and receptor status. Based on PAM50 gene expression signature, breast cancer is categorized into six "intrinsic" subtypes namely, Luminal A, Luminal B, HER2-enriched, 
Claudin-low, Basal-like, and Normal-like [2, 3, 4], of which, Basal-like type has poor prognosis [5]. Based on receptor status, breast cancer is categorized into estrogen receptor (ER)-positive type, progesterone receptor $(\mathrm{PgR})$ positive type, HER2 positive type, and triple-negative type (ER-negative, PgR- negative, HER2-negative) (TNBC). Among them, TNBC has the poorest prognosis. Notably, among $70-80 \%$ of Basal-like type of breast cancer has been reported to fall into TNBC category [6].

Tumors are comprised of population of cancer cells and distinct cancer stem cells (CSCs), which are largely undifferentiated tumorigenic cells with stemlike properties such as self-renewal and multipotency $[7,8]$. Most CSCs are resistant to conventional antitumor treatments, chemo- and radio-therapies, which consequently leads tumor recurrence and metastasis. Therefore, the development of targeted therapies against CSCs is highly required to improve poor clinical outcome.

CSCs in breast tumor patients can be identified based on the expression of aldehyde dehydrogenase (ALDH) isoforms. ALDH1 has been reported to be enriched in CSCs of several cancer types, including breast cancer and is a potential CSC marker [9, 10, 11]. Among ALDH1 gene family, isoforms $A L D H 1 A 1$ and $A L D H 1 A 3$ are also known as CSCs markers in several cancers [11, 12, 13, 14]. Particularly, isoform $A L D H 1 A 3$ has been reported to contribute significantly to ALDH1 activity in breast cancer cells and its expression significantly correlates with cancer type, tumor grade and metastasis in breast tumor patients [15]. On the other hand, there are controversial results regarding the involvement of ALDH1 in breast cancer subtypes $[16,17,18]$.

c-Met is a receptor-type tyrosine kinase, which is involved in wide range of cellular responses such as proliferation, motility, migration, invasion and tumor angiogenesis [19, 20]. c-Met has been reported to be highly expressed and aberrantly activated in variety of cancers [21, 22, 23]. High expression of c-Met correlating with the expression of CSCs markers such as CD133, CD44, and ALDH1 has also been reported [24, 25, 26]. Furthermore, c-Met protein has been reported to be involved in biological processes of head and neck, and pancreatic CSCs [26, 27]. However, the relationship of c-Met with ALDH1 positive CSCs in breast cancer subtypes still remains unclear.

In this study, we show that high expression of c-Met correlates with the expression of $A L D H 1 A 3$ in breast cancer. Patients with co-expression of $c$-Met and $A L D H 1 A 3$ at tumor stage III-IV showed poor clinical outcome. Furthermore, c-Met inhibitors suppressed the viability and tumor-sphere formation of ALDH $1{ }^{\text {high }}$ cells. These results suggest that c-Met is essential for the viability and tumor formation of ALDH1 positive breast CSCs. Therefore, c-Met protein is a promising therapeutic target for ALDH1 positive breast CSCs.

\section{RESULTS}

\section{Correlation of $\boldsymbol{c}$-Met with CSC markers at gene expression level in human breast cancers}

To investigate the association of $c$-Met with CSC markers such as ALDH1A1, ALDH1A3,CD44, and $C D 133$ at gene expression levels in human breast cancers,
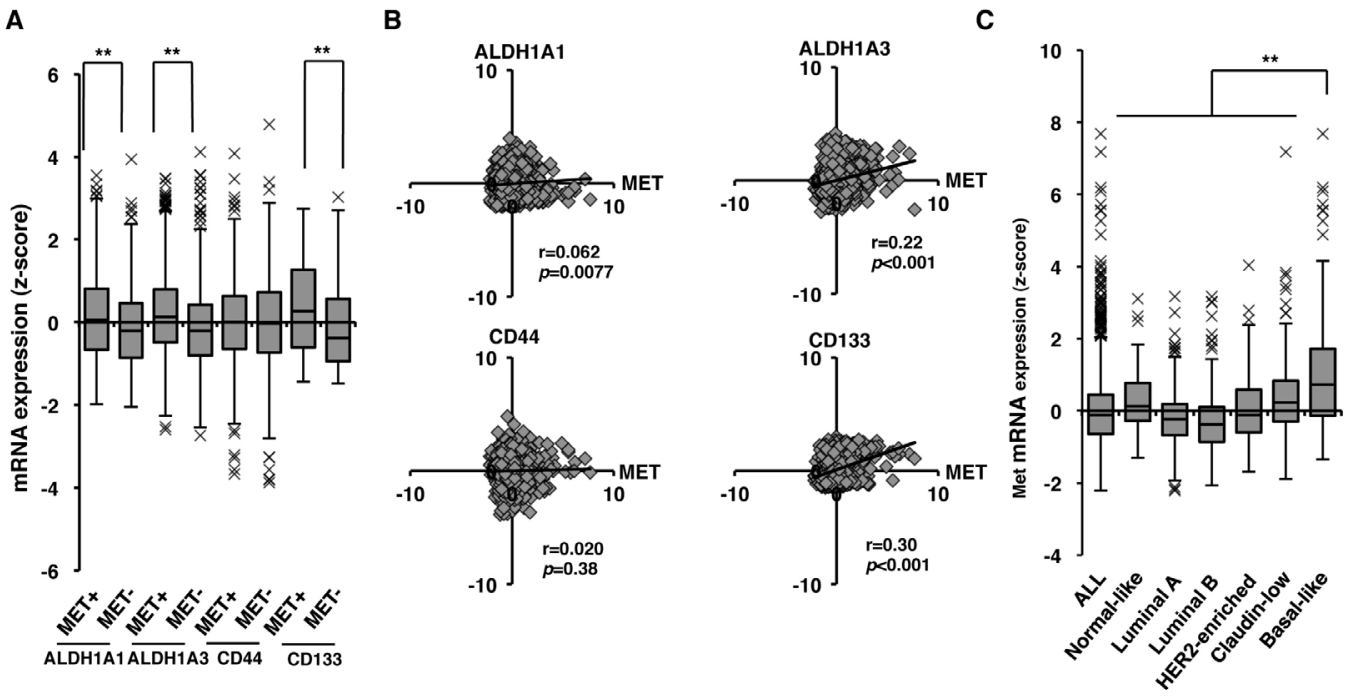

Figure 1: $\boldsymbol{c}$-Met expression correlates with gene expression of human breast CSC markers. A. Gene expression levels of $A L D H 1 A 1, A L D H 1 A 3, C D 44$, and CD133 with high (c-Met $\left.{ }^{+}\right)$and low (c-Met $\left.{ }^{-}\right) c-$ Met expression in primary breast tumors. Values are shown as box-and-whisker plot (Tukey's test, ${ }^{* *} p<0.01$ ). B. Correlation of $c$-Met with ALDH1A1, ALDH1A3, CD44, and CD133 in primary breast tumors. Values are shown as scattered plots. The coefficient of correlation (r) and the $p$ value $(p)$ are indicated. C. $c$-Met expression levels in breast cancer subtypes. Values are shown as box-and-whisker plot (Tukey's test, $*^{*} p<0.01$ ). 
Table 1: Correlation analysis between $c$-Met with cancer stem cell or undifferentiated markers in all stage, stage 0 , I, II and stage III, IV of breast tumors.

\begin{tabular}{|c|c|c|c|c|c|c|}
\hline \multirow{2}{*}{$\begin{array}{c}\text { mRNA co-expression } \\
\text { MET vs. }\end{array}$} & \multicolumn{2}{|c|}{ ALL Stage } & \multicolumn{2}{|l|}{ Stage I-II } & \multicolumn{2}{|l|}{ Stage III-IV } \\
\hline & $\begin{array}{l}\text { Pearson's } \\
\text { Correlation }\end{array}$ & $p$-value & Pearson's Correlation & $p$-value & Pearson's Correlation & $p$-value \\
\hline ALDH1A1 & 0.06 & 0.008 & 0.05 & 0.058 & -0.03 & 0.736 \\
\hline$A L D H 1 A 3$ & 0.22 & $<0.001$ & 0.21 & $<0.001$ & 0.40 & $<0.001$ \\
\hline CD44 & 0.02 & 0.381 & 0.01 & 0.857 & 0.04 & 0.637 \\
\hline$C D 133$ & 0.30 & $<0.001$ & 0.31 & $<0.001$ & 0.40 & $<0.001$ \\
\hline KLF4 & 0.10 & $<0.001$ & 0.11 & $<0.001$ & 0.12 & 0.181 \\
\hline$M Y C$ & 0.14 & $<0.001$ & 0.15 & $<0.001$ & 0.17 & 0.055 \\
\hline NANOG & -0.04 & 0.064 & -0.02 & 0.560 & 0.01 & 0.895 \\
\hline NOTCH1 & 0.17 & $<0.001$ & 0.16 & $<0.001$ & 0.43 & $<0.001$ \\
\hline NOTCH3 & 0.06 & 0.010 & 0.02 & 0.449 & 0.22 & 0.017 \\
\hline OCT4 & 0.02 & 0.325 & 0.00 & 0.888 & 0.35 & $<0.001$ \\
\hline$S O X 2$ & 0.00 & 0.882 & 0.01 & 0.730 & -0.05 & 0.609 \\
\hline STAT3 & -0.03 & 0.156 & -0.05 & 0.078 & -0.05 & 0.558 \\
\hline BMI1 & -0.16 & $<0.001$ & -0.17 & $<0.001$ & -0.20 & 0.023 \\
\hline
\end{tabular}

we analyzed mRNA data and the clinical information of 1904 patients of breast cancers from cBioPortal for Cancer Genomics [28, 29]. As shown in Figure 1A, high expression of $c$-Met $\left(\mathrm{MET}^{+}\right)$correlated with expression of CSC markers, ALDH1A1 ( $p<0.001)$, ALDH1A3 ( $p$ $<0.001)$, and $C D 133(p<0.001)$ in breast cancers. In addition, scatter plots analysis also indicated that $c-M e t$ expression correlated with ALDH1A1 ( $p=0.0077)$, $A L D H 1 A 3(p<0.001)$ and $C D 133$ expression $(p<0.001)$
(Figure 1B and Table 1). c-Met expression was also found to be associated with several undifferentiated markers, such as KLF4, c-Myc, Notch1, Notch3, and BMI1 (Table1). Next we examined the mRNA expression level of $c$-Met in the specific breast cancer subtypes. As shown in Figure $1 \mathrm{C}, c-$ Met mRNA was found to be enriched in Basal-like type in comparison with other subtypes, such as Normallike, Luminal A, Luminal B, HER2-enriched, and Claudinlow.
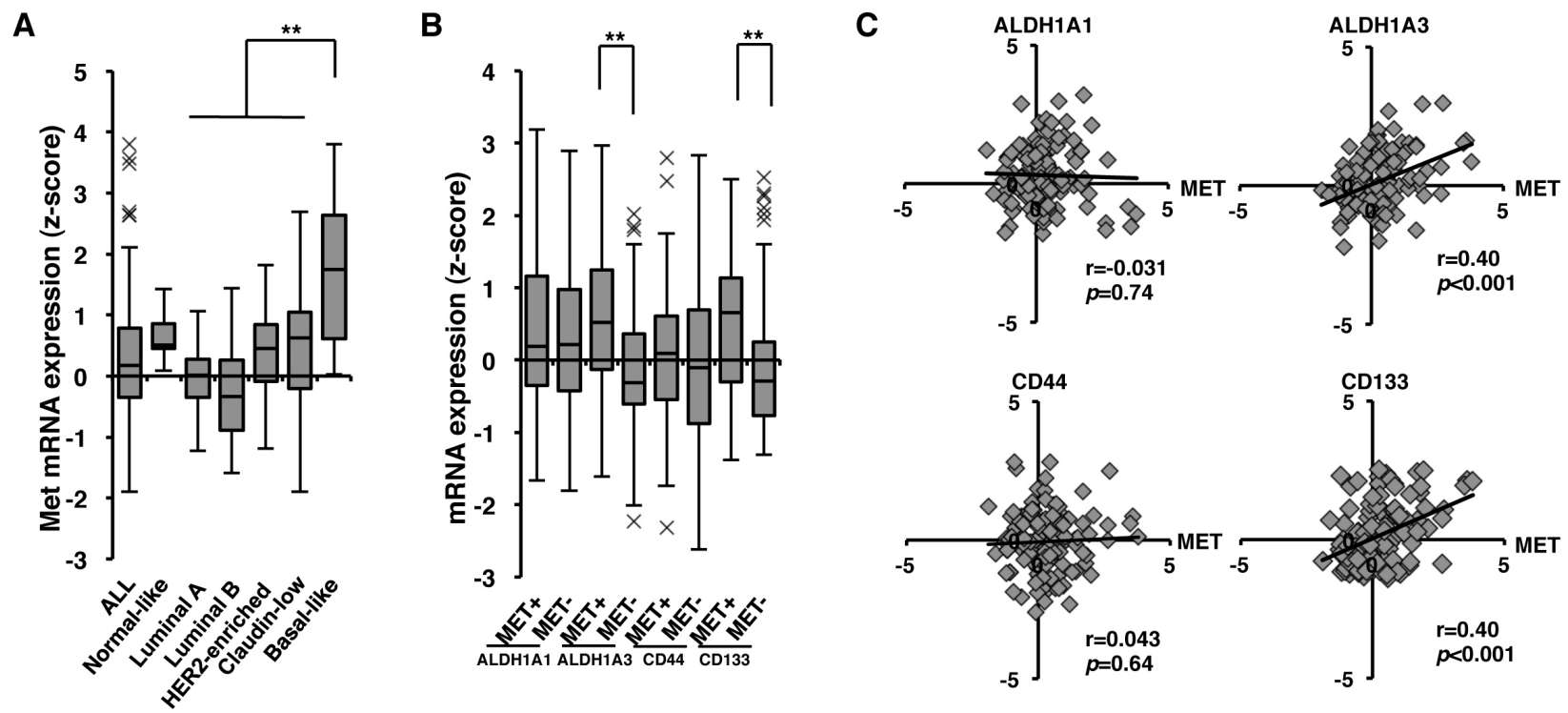

Figure 2: Correlation of $c$-Met with $A L D H 1 A 3$ and $C D 133$ at gene expression level in tumor stage III and IV of breast cancer. A. $c$-Met expression levels in breast cancer subtypes of tumor stage III-IV. Values are shown as box-and-whisker plot (Tukey's test, $\left.{ }^{* *} p<0.01\right)$. B. Gene expression levels of $A L D H 1 A 1, A L D H 1 A 3, C D 44$, and CD133 with high (c-Met $\left.{ }^{+}\right)$and low (c-Met $\left.{ }^{-}\right) c-M e t$ expression at tumor stage III-IV. Values are shown as box-and-whisker plot (Tukey's test, ${ }^{* *} p<0.01$ ). C. Correlation of $c-$ Met with $A L D H 1 A 1$, $A L D H 1 A 3, C D 44$, and $C D 133$ at tumor stage III-IV. Values are shown as scattered plots. The coefficient of correlation (r) and the $p$ value (p) are indicated. 
Table 2: List of c-Met inhibitors.

\begin{tabular}{|l|l|l|c|}
\hline Compound name & \multicolumn{1}{|c|}{ Action mechanism } & \multicolumn{1}{|c|}{ Targets } & Reference \\
\hline NVP-BVU972 & ATP competitive Met inhibitor & c-Met & 43 \\
\hline Tivantinib & ATP non-competitive Met inhibitor & c-Met & 41,42 \\
\hline BMS777607 & ATP competitive Met inhibitor & c-Met, RON, Axl, TYRO3 and MER & 44 \\
\hline AMG-208 & ATP competitive Met inhibitor & c-Met and RON & 45 \\
\hline Cabozantinib & ATP competitive Met inhibitor & c-Met, VEGFR, RET KIT, FLT3 and TIE2 & 46 \\
\hline Foretinib & ATP competitive Met inhibitor & c-Met, VEGFR, AXL, PDGFR, KIT, FLT3 and TIE2 & 47,48 \\
\hline PF-04217903 & ATP competitive Met inhibitor & c-Met & 49,50 \\
\hline Crizotinib & ATP competitive Met inhibitor & c-Met and ALK & 51,52 \\
\hline PHA-665752 & ATP competitive Met inhibitor & c-Met, RON, FLK1 and c-Abl & 53,54 \\
\hline
\end{tabular}

\section{Correlation of $c$-Met with $A L D H 1 A 3$ and $C D 133$ at gene expression level in breast cancer at tumor stage III-IV}

Since overexpression of c-Met contributes to cancerous progression $[21,22,23]$, we next examined $c$-Met expression at various tumor stages. Among early tumor stage lesions ( $0, \mathrm{I}, \mathrm{II} ; n=1279), 45 \%$ were c-Met $^{+}$ ( $\mathrm{n}=573)$, contrary to $59 \%$ of c-Met ${ }^{+}(n=74)$ at tumor late stage lesions (III, IV; $n=124$ ). As c-Met tumor lesions were higher in tumor stage III-IV, in contrast with stage 0 , I, and II, we next focused to analyze the relationship between $c$-Met gene expression and CSC markers in breast cancer subtypes at tumor stage III-IV. $c$-Met mRNA was found to be enriched in Basal-like type in comparison with other subtypes at stage III and IV (Figure 2A). As shown in Figure 2B, c- $\mathrm{Met}^{+}$strongly correlated with ALDH1 A3 ${ }^{+}$ $(p<0.001)$. c-Met ${ }^{+}$also weakly associated with $\mathrm{CD} 133^{+}$ $(p=0.0025)$. Scatter plots analysis also indicated that $c$-Met expression correlated with ALDH1A3 $(p<0.001)$ and $C D 133$ expression $(p<0.001)$ (Figure $2 \mathrm{C}$ and Table 1). $c$-Met expression was also found to be associated with several undifferentiated markers, such as Notch1, Oct4, and BMI1 (Table 1). These results indicate that c-Met plays important roles in ALDH1 and/or CD133 positive CSCs.

\section{Co-expression of $c-M e t^{\text {high }}$ and $A L D H 1 A 3^{\text {high }}$ indicated poor prognosis}

Further, we next performed Kaplan-Meier analysis of $c$-Met and CSC markers at tumor stage III-IV. $c-M e t^{\text {high }}$ patients did not show poor prognosis $(p=0.11)$ (Figure $3 \mathrm{~A})$, whereas $A L D H 1 A 3^{\text {high }}(p=0.0049)$ and $C D 133^{\text {high }}(p=$ 0.0088 ) showed poor prognosis (Figure $3 \mathrm{~B}$ ). Interestingly, co-expression of both $c-M e t^{\text {high }}$ with $A L D H 1 A 3^{\text {high }}(p=$ $0.0065)$, and with $C D 133^{\text {high }}(p=0.0023)$ indicated poor prognosis (Figure 3C). These results indicate that c-Met plays important roles in cancerous progression and contributed to the poor prognosis in ALDH1 positive and/ or CD133 positive breast CSCs. Since the role of c-Met in biological properties of CD133 positive CSCs is reported $[24,32,33]$, hence, we focused on investigating the roles of c-Met in ALDH1 positive breast CSCs.

\section{c-Met inhibitors suppressed viability of ALDH1 positive CSCs}

To reveal the role of c-Met in CSCs, we used MDAMB157 and MDA-MB468 cell lines derived from human Basal-like type of breast cancer. c-Met protein was found to be highly expressed in MDA-MB157 cells in contrast to MDA-MB468 cells (Figure 4A). Next, we examined the effects of nine c-Met inhibitors on the viability of MDAMB157 cells expressing higher c-Met protein (Table 2). Four c-Met inhibitors such as Crizotinib, Foretinib, PHA-665752 and Tivantinib strongly suppressed the viability of MDA-MB157 cells (Figure 4B). These results were consistent with the results of inhibition of c-Met phosphorylation level (indicating its activity) on treatment with c-Met inhibitors in MDA-MB157 cells (Figure 4C). Therefore, we next examined the inhibitory effects of these four c-Met inhibitors on the viability of ALDH 1 high cells derived from MDA-MB157 and MDA-MB468 cell lines. Isolated $\mathrm{ALDH} 1^{\text {high }}$ cells derived from both MDA-MB157 and MDA-MB468 cell lines showed CSCs properties such as self-renewal, multi-differentiation, and tumorigenesis (Supplementary Figure2A and 2B) as previously reported [9]. Interestingly, both c-Met and $\mathrm{p}$-Met expression is higher in ALDH1 $1^{\text {high }}$ cells than ALDH1 $1^{\text {low }}$ cells (Figure 5A). The result suggests that ALDH $1^{\text {high }}$ cells have high activity of c-Met. The c-Met inhibitors except for Tivantinib suppressed viability of ALDH $1^{\text {high }}$ cells in both cell lines. The $50 \%$ cell growth inhibitory concentrations $\left(\mathrm{IC}_{50}\right)$ of Crizotinib, Foretinib, 
and PHA-665752 were found to be lower in MDA-MB157 cells expressing higher c-Met protein than that in MDAMB468 cells expressing lower c-Met protein (Figure 5BD). Interestingly, Tivantinib specifically suppressed the viability of ALDH1 ${ }^{\text {high }}$ MDA-MB157 cells. These results suggest that c-Met is necessary for the viability of ALDH1 positive breast CSCs.

\section{c-Met inhibitors suppressed tumor-sphere formation of ALDH1 positive CSCs}

To investigate the role of c-Met in tumor formation of ALDH1 positive CSCs, we next examined the inhibitory effects of aforementioned inhibitory compounds on tumor-sphere formation in ALDH1 positive CSCs derived from MDA-MB157 in vitro system. As shown in Figure $6 \mathrm{~A}$ and $6 \mathrm{~B}$, the inhibitory compounds were observed to suppress tumor-sphere formation. The $\mathrm{IC}_{50}$ values of these compounds for tumor-sphere formation were $0.18 \mu \mathrm{M}$ (Crizotinib), $0.21 \mu \mathrm{M}$ (Foretinib), 3.4 $\mu \mathrm{M}$ (PHA-665752), and $0.18 \mu \mathrm{M}$ (Tivantinib) (Figure 6C). These results suggest that c-Met is essential for tumor-sphere formation of ALDH1 positive CSCs in breast cancer cells.

Taken together with aforementioned results, it can be inferred that c-Met is specifically essential for cell viability and tumor-sphere formation of ALDH1 positive human breast CSCs.

\section{DISCUSSION}

High expression of $c$-Met correlated with the expression of $A L D H 1 A 3$ in Basal-like type of breast cancer (Figure 1C). Since breast cancer stem cells exhibit a Basal-like phenotype [34], our result may thus provide new insights into the role of c-Met in ALDH1 positive CSCs of Basal-like type of breast cancer. It has been reported that knock-down of c-Met by siRNA and inhibitor treatment results in decrease of $A L D H 1 A 3$ gene expression and ALDEFLUOR activity in pancreatic cancer cell lines with high levels of c-Met [25]. Similarly, high c-Met expression and its activation are also suggested to be involved in the promotion of $A L D H 1 A 3$ gene expression in Basal-like type of breast cancer.

Several studies have reported that patients with higher expression of ALDH1 have poor prognosis in several cancers $[9,35]$. In our study, Kaplan-Meier analysis revealed that patients with high $A L D H 1 A 3$ expression at tumor stage III-IV had poor outcome $(p=0.0049$, Figure 3B). Similarly, patients expressing both $c$-Met and $A L D H 1 A 3$ at tumor stage III-IV had poor prognosis $(p=$
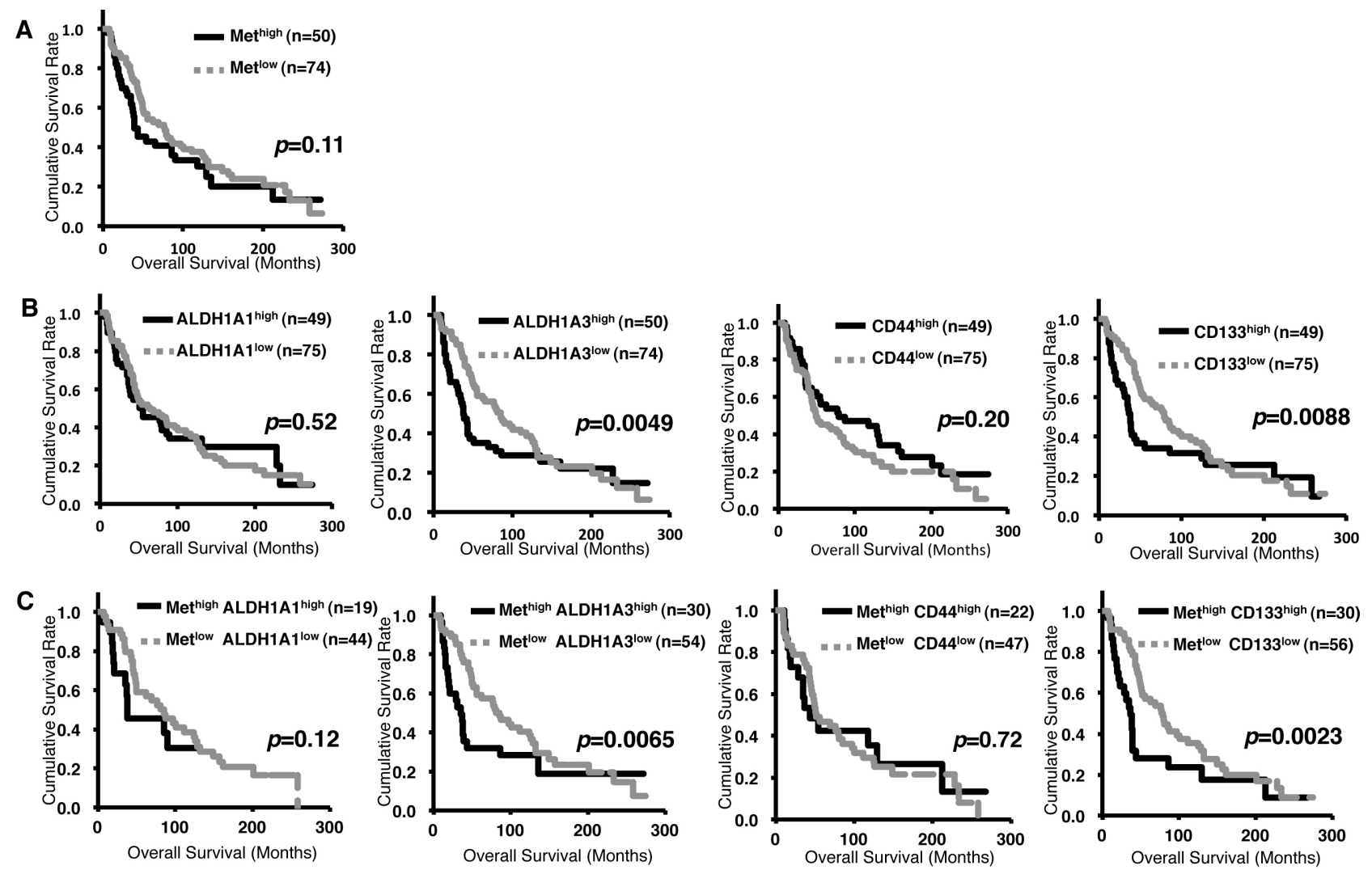

Figure 3: Co-expression of $c$-Met with $A L D H 1 A 3$ or $C D 133$ contributes to poor prognosis in breast cancer patients at tumor stage III-IV. Kaplan-Meier Survival curves of human breast cancer at tumor stage III-IV. A. $c$-Met expression. B. ALDH1A1, ALDH1A3, CD44 or CD133 expression. C. c-Met and ALDH1A1, ALDH1A3, CD44 or CD133 expression. 
0.0065, Figure 3C). c-Met was found to be enriched in Basal-like type in comparison with other subtypes (Figure 1 and 2). However, patients expressing high $c$-Met and $A L D H 1 A 3$ in Basal-like type did not show poor outcome ( $p=0.20 ; n=199$, Supplementary Figure 1D), which could be attributed to no correlation between $c$-Met and $A L D H 1 A 3$ in Basal-like type (Supplementary Figure 1A, $p=0.58, \mathrm{r}=0.039)$. In spite of no correlation between c-Met and ALDH1A3 expression, major population of Basal-like type patients expressed high expression of c-Met and ALDH1A3 ( $n=93$ in 199). Therefore, c-Met may play an important role in cancerous progression in Basal-like type. On the other hands, at tumor stage III-IV, of total analyzed patient samples $(n=124)$, each subtypes were distributed as follows; Luminal A $(23 \%, n=28)$, Luminal B $(28 \%, n=35)$, HER2-enriched $(17 \%, \mathrm{n}=21)$, Claudin-low $(16 \%, n=20)$, Normal-like $(5 \%, n=6)$, and Basal-like $(11 \%, n=14)$. Therefore, co-expression of both c-Met and ALDH1A3 at late tumor stages may contribute to poor clinical outcome not only in Basal-like but also in other subtypes. Since efficacy of chemotherapy at cancer spreading stage III-IV is extremely crucial, targeting c-Met in ALDH1 positive breast CSC may possibly decrease the severity of metastatic breast cancer and hence may lead to the survival of breast cancer patients. In addition, previous studies reported that ALDH1 is required for maintaining a drug-resistant cell subpopulation of stomach and breast cancer cells [36, 37, 38, 39]. Therefore, considering this, the drug resistance characteristics of breast cancers expressing $c$-Met and $A L D H 1 A 3$ should be analyzed in detail in the future for targeted cancer therapy.

We found that c-Met inhibitors suppressed cell viability and tumor-sphere formation of ALDH1 $1^{\text {high }}$ cells (Figure 5 and 6). ALDH1 enzyme catalyzes the oxidation of aldehydes into corresponding acetic acids, and is involved in detoxification of toxic aldehyde intermediates produced in cancer cells. Recent studies reported that ALDH1 decreases ROS levels in various cancer cells and metabolizes toxic aldehydes formed by lipid peroxidation generated from intracellular lipids due to $\operatorname{ROS}[36,40]$. Since we observed strong correlation between ALDH1 and c-Met, use of c-Met inhibitors in ALDH1 ${ }^{\text {high }}$ cells may have accumulated ROS and toxic aldehydes, which consequently may have lead to the induction of apoptosis in cancer cells.

Thus, it is suggested that c-Met plays an important role in ALDH1 positive breast CSCs. Although the ALDH $1^{\text {high }}$ cells derived from MDA-MB157 and MDAMB468 cells have been cultured in vitro in the presence of FBS, no loss in CSCs properties was observed (Supplementary Figure2A and 2B). Since, loss of stem cell property due to long term culture of cells in in vitro in

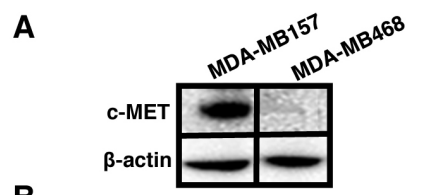

C
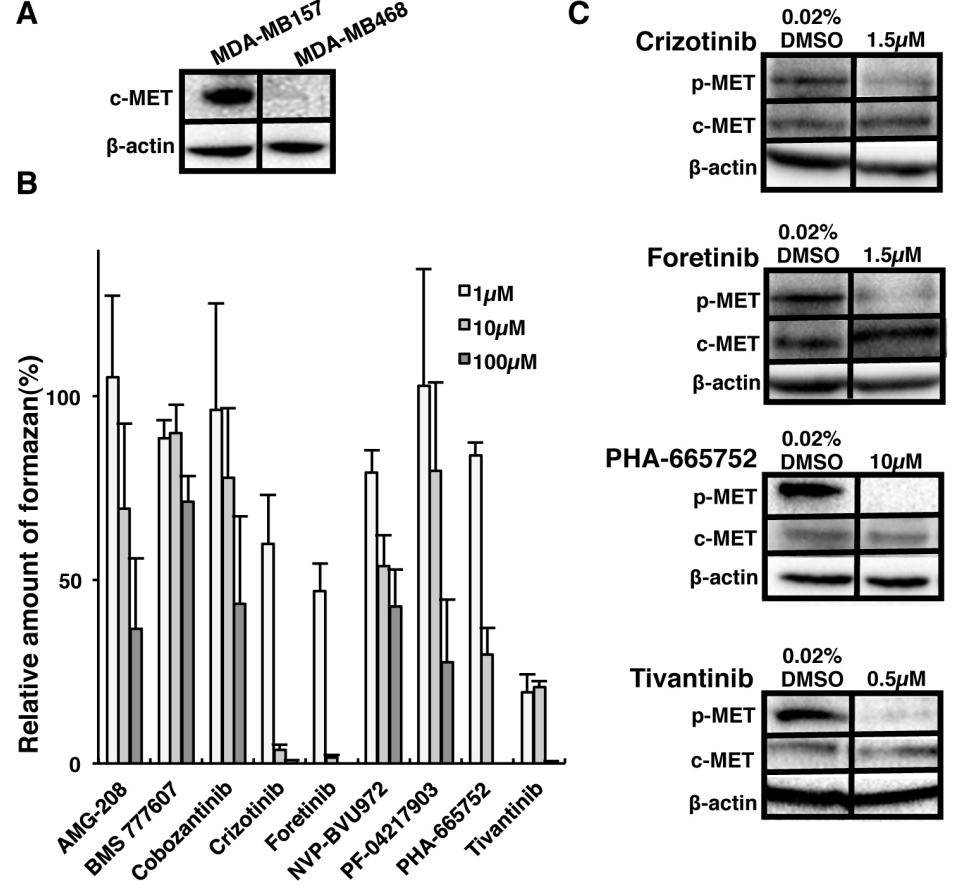

Figure 4: c-Met inhibitors suppressed cell viability and c-Met activation in Basal-like type of breast cancer cell lines. A. $c$-Met expression in Basal-like type of breast cancer cell lines, MDA-MB157 and MDA-MB468 were analyzed by Immunoblot. $\beta$-actin was used as an internal control. B. Viability of MDA-MB157 cells after treatment with c-Met inhibitors $(1,10$ and $100 \mu \mathrm{M})$ compared with $0.02 \%$ DMSO for 3 days was assessed by the amount of formazon formed by WST assay. Numerical values of test groups are shown with respect to $0.02 \%$ DMSO treated group. All data is represented as the mean \pm S.D. of three independent experiments. C. c-Met phosphorylation level in MDA-MB157 was analyzed by immunoblot. MDA-MB157 cells were treated for $6 \mathrm{~h}$ with Crizotinib (1.5 $\mu \mathrm{M})$, Foretinib $(1.5 \mu \mathrm{M})$, PHA-665752 $(10 \mu \mathrm{M})$ and Tivantinib $(0.5 \mu \mathrm{M})$. 
the presence of FBS has been reported, hence appropriate measures should be taken for long term culture of CSCs.

Among c-Met inhibitors, Crizotinib, Foretinib, PHA-665752 and Tivantinib, only Tivantinib specifically suppressed viability of high c-Met expressing MDAMB157 cells as compared to low c-Met expressing MDAMB468 cells (Figure 5). These results may depend on the inhibitory mechanisms of Tivantinib against c-Met activity. The c-Met inhibitors except Tivantinib are ATP competitor that docks to active site of c-Met kinase. ATP competitors generally inhibit the activity of other kinases and function of ATP associated molecules. In fact, Crizotinib, Foretinib and PHA-665752 strongly suppress the cell viability by inhibition of other kinases and ATP associated molecules (Table 2). On the other hand, Tivantinib, a non-ATP competitor, inhibits c-Met autophosphorylation and is highly selective for the inactive or non-phosphorylated form of c-Met by binding to ATP-binding cleft [41, 42]. Furthermore, the specific inhibitory effect of Tivantinib is profiled against 230 human kinases [41]. Non-ATP competitor such as Tivantinib binding to allosteric site must be explored further, as it may contribute to develop specific drugs targeting to c-Met in the future.

\section{CONCLUSION}

In this study, we showed that high expression of $c$-Met correlated with the expression of $A L D H 1 A 3$ in Basal-like type of breast cancer. Patients with co- expression of $c$-Met and $A L D H 1 A 3$ at tumor stage IIIIV showed poor clinical outcome. Furthermore, c-Met inhibitors suppressed the cell viability and tumor-sphere formation of ALDH $1{ }^{\text {high }}$ cells. These results suggest that c-Met is essential for the viability and tumor formation of ALDH1 positive CSCs. Therefore, c-Met protein is potential therapeutic target for ALDH1 positive breast CSCs.

\section{MATERIALS AND METHODS}

\section{Cell culture}

Human Basal-like type of breast cancer cell lines (MDA-MB157 and MDA-MB468) were obtained from American Type Culture Collection (ATCC, Manassas, VA, USA). Cell lines were grown in Dulbecco's Modified Eagle Medium (DMEM) medium supplemented with 10\% fetal bovine serum (FBS) (Biosera, Dominican Republic) and penicillin/streptomycin. Cells were cultured at $37^{\circ} \mathrm{C}$ in a humidified atmosphere with $95 \%$ air $/ 5 \% \mathrm{CO}_{2}$.

\section{c-Met inhibitors and antibodies}

c-Met inhibitors (AMG-208, BMS 777607, Cabozantinib, Crizotinib, Foretinib, NVP-BVU972, PF04217903, PHA-665752, Tivantinib) were purchased from
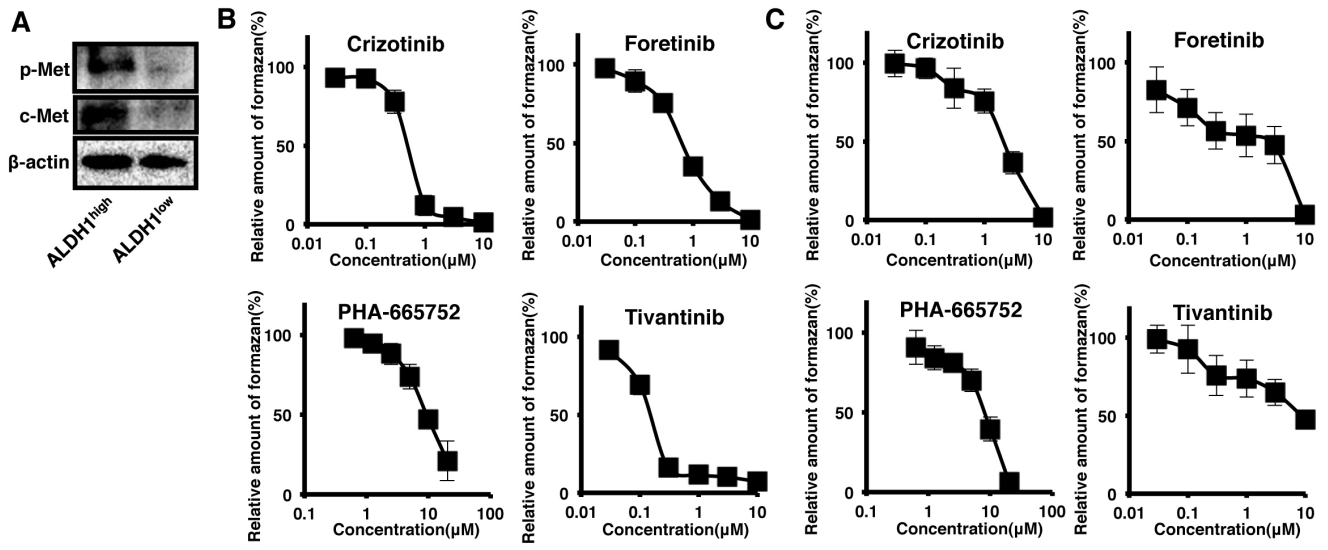

\begin{tabular}{|c|c|c|c|c|c|c|c|c|}
\hline \multirow[b]{2}{*}{ Cell line } & \multicolumn{2}{|c|}{ Crizotinib } & \multicolumn{2}{|c|}{ Foretinib } & \multicolumn{2}{|c|}{ PHA-665752 } & \multicolumn{2}{|c|}{ Tivantinib } \\
\hline & $\begin{array}{c}\text { MDA-MB } \\
157\end{array}$ & $\begin{array}{c}\text { MDA-MB } \\
468\end{array}$ & $\begin{array}{c}\text { MDA-MB } \\
157\end{array}$ & $\begin{array}{c}\text { MDA-MB } \\
468\end{array}$ & $\begin{array}{c}\text { MDA-MB } \\
157\end{array}$ & $\begin{array}{c}\text { MDA-MB } \\
468\end{array}$ & $\begin{array}{c}\text { MDA-MB } \\
157\end{array}$ & $\begin{array}{c}\text { MDA-MB } \\
468\end{array}$ \\
\hline $\mathrm{IC}_{50}(\boldsymbol{\mu} \mathrm{M})$ & $0.63 \pm 0.09$ & $2.32 \pm 0.21$ & $0.73 \pm 0.08$ & $2.15 \pm 1.35$ & $7.31 \pm 2.83$ & $8.35 \pm 0.45$ & $0.17 \pm 0.01$ & $9.45 \pm 3.61$ \\
\hline
\end{tabular}

Figure 5: c-Met inhibitors suppressed viability of ALDH1 ${ }^{\text {high }}$ cells derived from Basal-like type of breast cancer cells lines. A. c-Met and Phosphorylated c-Met (p-Met) expression in ALDH1 $1^{\text {high }}$ or ALDH1 $1^{\text {low }}$ cells from MDA-MB157 were analyzed by Immunoblot. $\beta$-actin was used as an internal control. B.-C. Cell viability based on formation of formazon product as assessed by the WST-1 assay after 3 days of treatment with c-Met inhibitors, Crizotinib, Foretinib, PHA-665752, and Tivantinib $(0.03,0.1,0.3,1,3$ and $10 \mu \mathrm{M})$ in ALDH $1^{\text {high }}$ cells derived from MDA-MB157 (B) and MDA-MB468 (C). Numerical values of test groups are shown with respect to $0.02 \%$ DMSO treated group. D. In vitro $\mathrm{IC}_{50}$ values of c-Met inhibitors in ALDH1 $1^{\text {high }}$ cells derived from MDA-MB 157 and MDA-MB 468 . All data is represented as the mean \pm S.D. from three independent experiments. 
Namiki Inc. (Japan). All compounds dissolved in DMSO. Rabbit polyclonal c-Met antibody was purchased from Santa Cruz Inc. (USA). Rabbit monoclonal phospho-Met (Tyr1234/1235) antibody, HRP-conjugated anti-rabbit IgG and anti-mouse IgG were purchased from Cell Signaling Technology (USA). Mouse monoclonal $\beta$-actin antibody was obtained from Wako Inc. (Japan).

\section{Flow cytometry}

Cells were exfoliated from culture dish by accutase (Innovative Cell Technology) and filtered through $40 \mu \mathrm{m}$ cell strainers (Greiner) to obtain single cells. The ALDH $1^{\text {high }}$ cells were isolated from MDA-MB157 and MDA-MB468 cells by ALDEFLUOR assay kit (Stem Cell Technology) or AldeRed ALDH detection assay kit (MERCK) according to the manufacturer's instructions. Briefly, cells $\left(2 \times 10^{6}\right)$ were incubated with the substrate for ALDH1 $(5 \mu \mathrm{L}$ substrate $/ \mathrm{mL}$ medium) for $30 \mathrm{~min}$ at $37^{\circ} \mathrm{C}$. As a negative control for the ALDEFLUOR assay and AldeRed assay, cells were incubated with ALDH1 inhibitor, diethylaminobenzaldehyde (DEAB). The ALDH $1^{\text {high }}$ cells were sorted by cell sorter (FACS AriaII, $\mathrm{BD}$ Bioscience) by taking the negative control into consideration. The analysis of CD10/EpCAM positive cells from MDA-MB157 and MDA-MB468 cells. Suspended MDA-MB468 cells $\left(1 \times 10^{6}\right)$ were incubated with anti-CD10 (APC) (BD Bioscience) and anti-EpCAM
(PE) (BD Bioscience) for $1 \mathrm{hr}$ on ice, after which the sample was washed with fresh FACS buffer ( $2 \%$ FBS in $1 \times$ PBS (-)). For this experiments, cells were analyzed using a FACS Calibur (BD Bioscience).

\section{WST-8 assay}

Cells $\left(3 \times 10^{5} /\right.$ well $)$ were seeded into 96 well culture plate (Sigma). One day post seeding, cells were treated with c-Met inhibitors for 3, 5, and 7 days. Cell viability was detected by WST- 8 assay (Cell Counting Kit-8 (DOJINDO)). The formazan dye formed was measured by $\mathrm{ARVO}^{\mathrm{TM}} \mathrm{MX}$ (PerkinElmer) at $450 \mathrm{~nm}$. Numerical values of test groups are shown with respect to $0.02 \%$ DMSO treated group.

\section{Immunoblotting}

Cells were dissolved in RIPA buffer $(50 \mathrm{mM}$ Tris (pH 8.0), $150 \mathrm{mM} \mathrm{NaCl}, 0.5 \mathrm{w} / \mathrm{v} \%$ sodium deoxycholate, $0.1 \mathrm{w} / \mathrm{v} \%$ SDS, $1.0 \mathrm{w} / \mathrm{v} \%$ Nonidet P-40 and protease inhibitor cocktail (Thermo Fisher)). Eight $\mu$ g of whole cell lysate proteins was electrophoresed by SDS-PAGE $(8 \%$ gel) and transferred to Immobilon-P Transfer Membrane (Millipore) or Immobilon-FL Transfer Membrane (Millipore). The transferred membranes were then blocked with $5 \%$ BSA in TTBS $(25 \mathrm{mM}$ Tris $(\mathrm{pH} 7.5), 140 \mathrm{mM}$ $\mathrm{NaCl}, 2.5 \mathrm{mM} \mathrm{KCl}$ and $0.1 \%$ Tween 20 ) and incubated

A

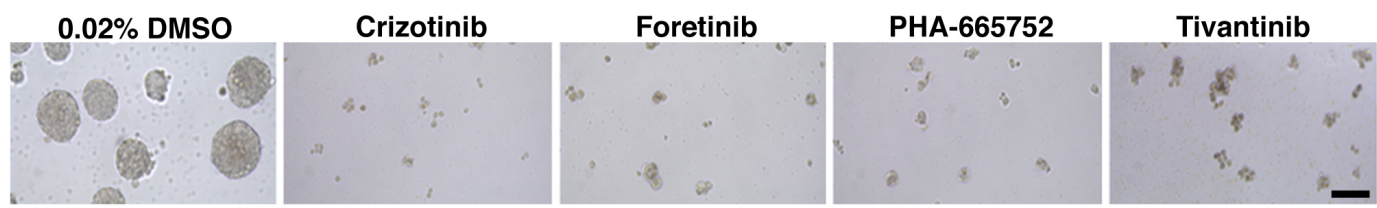

B
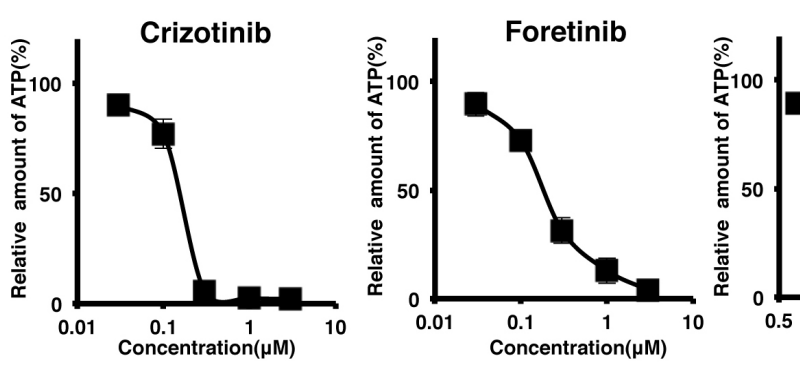

PHA-665752

C

\begin{tabular}{lcccc} 
& Crizotinib & Foretinib & PHA-665752 & Tivantinib \\
\cline { 2 - 5 } $\mathrm{IC}_{50}(\mu \mathrm{M})$ & $0.08 \pm 0.01$ & $0.21 \pm 0.02$ & $3.37 \pm 0.28$ & $0.18 \pm 0.01$ \\
\hline
\end{tabular}

Figure 6: c-Met inhibitors suppressed tumor-sphere formation of ALDH1 ${ }^{\text {high }}$ breast cancer cells. A. Tumor-spheres of ALDH $1^{\text {high }}$ cells derived from MDA-MB157 cells were incubated with c-Met inhibitors, Crizotinib $(1 \mu \mathrm{M})$, Foretinib (1 $\left.\mu \mathrm{M}\right)$, PHA-665752 $(10 \mu \mathrm{M})$ and Tivantinib $(1 \mu \mathrm{M})$ for 6 days. B. ATP level was assessed by the Cell-Titer Glo assay after treating tumor-spheres for 6 days with c-Met inhibitors, Crizotinib, Foretinib, Tivantinib $(0.03,0.1,0.3,1$, and $3 \mu \mathrm{M})$ and PHA-665752 $(0.6125,1.25,2.5,5$, and $10 \mu \mathrm{M})$. C. In vitro $\mathrm{IC}_{50}$ values with respect to decrease in $\mathrm{ATP}$ level on treatment with c-Met inhibitors. Numerical values of test groups are shown with respect to $0.02 \%$ DMSO treated group. All data is represented as the mean \pm S.D. from three independent experiments. Scale bar, $100 \mu \mathrm{m}$. 
with the primary antibodies. The membranes were then probed with the horseradish peroxidase-conjugated secondary antibody. Specific signals were detected by chemiluminescence reagent, such as Immunostar LD/ Immunostar Basic (Wako) using ChemiDoc MP (BioRad).

\section{Tumor-sphere culture}

Tumor-spheres were grown in DMEM culture medium containing $10 \%$ FBS, penicillin and streptomycin, 0.6\% methyl cellulose (Wako), and 0.05 $\mathrm{mM}$ 2-mercaptoethanol (Sigma) at $37^{\circ} \mathrm{C}$ in a humidified atmosphere with $95 \%$ air $/ 5 \% \mathrm{CO}_{2}$. ALDH $1^{\text {high }}$ cells $\left(1 \times 10^{3} /\right.$ well) were seeded and cultured in ultra low attachment 96well plate (Greiner) for 6 days with or without inhibitory compounds. CellTiter-Glo ${ }^{\circledR}$ luminescence assay (Promega) was performed by TR717 Micro plate Luminometer (TROPIX) using 96 well Micro-assay-plate (Greiner). Numerical values of test groups are shown with respect to $0.02 \%$ DMSO treated group.

\section{Analysis of gene expression data}

Gene expression data was analyzed using METABRIC, Nature 2012 \& Nat. Commun. 2016 dataset deposited in cBioPortal [28, 29, 30, 31]. Clinical data of the breast cancer patients used in our present study are summarized in Table S1. The median age at diagnosis was 61.1 years (aged 21.9 to 96.3 years). The dataset contains mRNA expression data of 1,904 primary breast tumor samples (patients) with details of breast cancer subtype (Normal-like, $n=140$; Luminal A, $n=679$; Luminal B, $n=461$; HER2-enriched, $n=220$; Claudin-low, $n=199$; Basal-like, $n=199$; Not classified, $n=6$ ). We retrieved the mRNA expression (Z-scores) of genes and evaluated co-expression of $c$-Met and several stem cell markers in either all or each of the tumor stage groups. We defined the $c$-Met expression as follows; all stage patients were divided into $\mathrm{c}-\mathrm{Met}^{+}$(c-Met $\mathrm{mRNA}$ expression Z-score $>0$, $n=837$ ) and c-Met'(c-Met mRNA expression Z-score < $0, n=1067)$ in Figure 1A, 1C and Table1. Tumor stage III and IV patients were classified into c-Met ${ }^{+}(\mathrm{c}-\mathrm{Met}$ mRNA expression Z-score $>0, n=74$ ) and c-Met-(c-Met mRNA expression Z-score $<0, n=50$ ) in Figure 2A, 2B and Table1. Pearson's correlation coefficiency was calculated for these expression levels for the subtypes in Figure 1B, $2 \mathrm{C}$ and Table1. We also compared $c$-Met expression in all or stage III-IV groups. Quantitative variables were analyzed by Tukey's test. Data with $p$ value less than 0.05 were considered significant. Survival curves were plotted by the Kaplan-Meier method and compared by the GehanBreslow generalized Wilcoxon test using BellCurve for Excel ver2.11. "High" and "low" were defined as the upper top $40 \%$ and the lower $60 \%$ of Z-score respectively, in several genes at stages III-IV breast cancer patients. Follow-up period after diagnosis ranged from 5.8 to 274.3 months stages III-IV breast cancer patients.

\section{ACKNOWLEDGMENTS}

We would like to thank Dr. T. Sato for helpful discussion on statistical analysis. We are also extremely grateful to Dr. B. Shashni for proof reading the article. This work was supported by the MEXT-Supported Program for the Strategic Research Foundation at Private Universities, 2014-2018. This work was supported in part by Grant-in-Aid for Scientific Research, Japan Society for the Promotion of Science to N.S. (\#23300365, \#15H04315).

\section{CONFLICTS OF INTEREST}

There is no conflict of interest.

\section{REFERENCES}

1. Ferlay J, Soerjomataram I, Dikshit R, Eser S, Mathers C, Rebelo M, Parkin DM, Forman D, Bray F. Cancer incidence and mortality worldwide: sources, methods and major patterns in GLOBOCAN 2012. Int J Cancer. 2015; 136: E359-386.

2. Parker JS, Mullins M, Cheang MC, Leung S, Voduc D, Vickery T, Davies S, Fauron C, He X, Hu Z, Quackenbush JF, Stijleman IJ, Palazzo J, et al. Supervised Risk Predictor of Breast Cancer Based on Intrinsic Subtypes. J Clin Oncol. 2009; 27: 1160-1167.

3. Prat A, Pineda E, Adamo B, Galván P, Fernández A, Gaba L, Díez M, Viladot M, Arance A, Muñoz M. Clinical implications of the intrinsic molecular subtypes of breast cancer. Breast. 2015; 24: S26-S35.

4. Sweeney C, Bernard PS, Factor RE, Kwan ML, Habel LA, Quesenberry CP Jr, Shakespear K, Weltzien EK, Stijleman IJ, Davis CA, Ebbert MT, Castillo A, Kushi LH, et al. Intrinsic Subtypes from PAM50 Gene Expression Assay in a Population-Based Breast Cancer Cohort: Differences by Age, Race, and Tumor Characteristics. Cancer Epidemiol Biomarkers Prev. 2015; 23: 714-724.

5. Lønning PE, Sørlie T, Børresen-Dale AL. Genomics in breast cancer-therapeutic implications. Nature Reviews Clinical Oncology. 2005; 2: 26-33.

6. Badve S, Dabbs DJ, Schnitt SJ, Baehner FL, Decker T, Eusebi V, Fox SB, Ichihara S, Jacquemier J, Lakhani SR, Palacios J, Rakha EA, Richardson AL, et al. Basallike and triple-negative breast cancers: a critical review with an emphasis on the implications for pathologists and oncologists. Mod Pathol. 2011; 24: 157-167.

7. Visvader JE, Lindeman GJ. Cancer Stem Cells: Current Status and Evolving Complexities. Cell Stem Cell. 2012; 10: 717-728. 
8. Reya T, Morrison SJ, Clarke MF, Weissman IL. Stem cells, cancer, and cancer stem cells. Nature. 2001; 1: 105-111.

9. Ginestier C, Hur MH, Charafe-Jauffret E, Monville F, Dutcher J, Brown M, Jacquemier J, Viens P, Kleer CG, Liu S, Schott A, Hayes D, Birnbaum D, et al. ALDH1 is a marker of normal and malignant human mammary stem cells and a predictor of poor clinical outcome. Cell Stem Cell. 2007; 1: 555-567.

10. Jiang F, Qiu Q, Khanna A, Todd NW, Deepak J, Xing L, Wang H, Liu Z, Su Y, Stass SA, Katz RL. Aldehyde dehydrogenase 1 is a tumor stem cell-associated marker in lung cancer. Mol Cancer Res. 2009; 7: 330-338

11. Su Y, Qiu Q, Zhang X, Jiang Z, Leng Q, Liu Z, Stass SA, Jiang F. ALDH1A1 Positive Cell Population Is Enriched in Tumorinitiating Cells and Associated with Progression of Bladder Cancer. Cancer Epidemiol Biomarkers Prev. 2010; 19: 327-337.

12. Landen CN Jr, Goodman B, Katre AA, Steg AD, Nick AM, Stone RL, Miller LD, Mejia PV, Jennings NB, Gershenson DM, Bast RC Jr, Coleman RL, Lopez-Berestein G, et al. Targeting Aldehyde Dehydrogenase Cancer Stem Cells in Ovarian Cancer. Molecular Cancer Therapeutics. 2010; 9: 3186-3199.

13. Cojoc M, Peitzsch C, Kurth I, Trautmann F, KunzSchughart LA, Telegeev GD, Stakhovsky EA, Walker JR, Simin K, Lyle S, Fuessel S, Erdmann K, Wirth MP, et al. Aldehyde Dehydrogenase Is Regulated by $\beta$-Catenin/TCF and Promotes Radioresistance in Prostate Cancer Progenitor Cells. Cancer Res. 2015; 75: 1482-1494.

14. Marcato P, Dean CA, Liu RZ, Coyle KM, Bydoun M, Wallace M, Clements D, Turner C, Mathenge EG, Gujar SA, Giacomantonio CA, Mackey JR, Godbout R, et al. Aldehyde dehydrogenase 1A3 influences breast cancer progression via differential retinoic acid signaling. Mol Oncol. 2015; 9: 17-31.

15. Marcato P, Dean CA, Pan D, Araslanova R, Gillis M, Joshi M, Helyer L, Pan L, Leidal A, Gujar S, Giacomantonio CA, Lee PW. Aldehyde Dehydrogenase Activity of Breast Cancer Stem Cells is Primarily Due to Isoform ALDH1A3 and Its Expression is Predictive of Metastasis. Stem Cells. 2011; 29: 32-45.

16. Nakshatri H, Srour EF, Badve S. Breast Cancer Stem Cells and Intrinsic Subtypes: Controversies Rage On. Current Stem Cell Research \& Therapy. 2009; 4: 50-60.

17. Tsang JY, Huang YH, Luo MH, Ni YB, Chan SK, Lui PC, Yu AM, Tan PH, Tse GM. Cancer stem cell markers are associated with adverse biomarker profiles and molecular subtypes of breast cancer. Breast Cancer Research and Treatment. 2012; 136: 407-417.

18. Ricardo S, Vieira AF, Gerhard R, Leitão D, Pinto R, Cameselle-Teijeiro JF, Milanezi F, Schmitt F, Paredes J. Breast cancer stem cell markers CD44, CD24 and ALDH1: expression distribution within intrinsic molecular subtype. J Clin Pathol. 2011; 64: 937-946.
19. Organ SL, Tsao MS. An overview of the c-MET signaling pathway. Therapeutic Advances in Medical Oncolog. 2011; 3: 7-19.

20. Abounader R, Laterra J. Scatter factor/hepatocyte growth factor in brain tumor growth and angiogenesis. NeuroOncology. 2005; 7: 436-451.

21. Miller CT, Lin L, Casper AM, Lim J, Thomas DG, Orringer MB, Chang AC, Chambers AF, Giordano TJ, Glover TW, Beer DG. Genomic amplification of MET with boundaries within fragile site FRA7G and upregulation of MET pathways in esophageal adenocarcinoma. Oncogene. 2006; 25: 409-418.

22. Okuda K, Sasaki H, Yukiue H, Yano M, Fujii Y. Met gene copy number predicts the prognosis for completely resected non-small cell lung cancer. Cancer Sci. 2008; 99: 22802285 .

23. Liu X, Newton RC, Scherle PA. Developing c-MET pathway inhibitors for cancer therapy: progress and challenges. Trends Mol Med. 2010; 16: 37-45.

24. Rath P, Lal B, Ajala O, Li Y, Xia S, Kim J, Laterra J. In Vivo c-Met Pathway Inhibition Depletes Human Glioma Xenografts of Tumor-Propagating Stem-Like Cells. Transl Oncol. 2013; 6: 104-111.

25. Kim IG, Lee JH, Kim SY, Kim JY, Cho EW. Fibulin-3 negatively regulates ALDH1 via c-MET suppression and increases $\gamma$-radiation-induced sensitivity in some pancreatic cancer cell lines. Biochem Biophys Res Commun. 2014; 454: 369-375.

26. Lim YC, Kang HJ, Moon JH. c-Met pathway promotes selfrenewal and tumorigenecity of head and neck squamous cell carcinoma stem-like cell. Oral Oncology. 2014; 50: 633 639.

27. Noguchi K, Eguchi H, Konno M, Kawamoto K, Nishida N, Koseki J, Wada H, Marubashi S, Nagano H, Doki Y, Mori M, Ishii H. Susceptibility of pancreatic cancer stem cells to reprogramming. Cancer Sci. 2015; 106: 1182-1187.

28. Curtis C, Shah SP, Chin SF, Turashvili G, Rueda OM, Dunning MJ, Speed D, Lynch AG, Samarajiwa S, Yuan Y, Gräf S, Ha G, Haffari G, et al. The genomic and transcriptomic architecture of 2,000 breast tumours reveals novel subgroups. Nature. 2012; 486: 346-352.

29. Pereira B, Chin SF, Rueda OM, Vollan HK, Provenzano E, Bardwell HA, Pugh M, Jones L, Russell R, Sammut SJ, Tsui DW, Liu B, Dawson SJ, et al. The somatic mutation profiles of 2,433 breast cancers refine their genomic and transcriptomic landscapes. Nat Commun. 2016; 7: 11479.

30. Cerami E, Gao J, Dogrusoz U, Gross BE, Sumer SO, Aksoy BA, Jacobsen A, Byrne CJ, Heuer ML, Larsson E, Antipin Y, Reva B, Goldberg AP, et al. The cBio Cancer Genomics Portal: an open platform for exploring multidimensional cancer genomics data. Cancer Dicov. 2012; 2: 401-404.

31. Gao J, Aksoy BA, Dogrusoz U, et al. Integrative analysis of complex cancer genomics and clinical profiles using the cBioPortal. Sci Signal. 2013; 6: 11. 
32. Nautiyal J, Kanwar SS, Yu Y, Majumdar AP. Combination of dasatinib and curcumin eliminates chemo-resistant colon cancer cells. J Mol Signal. 2011; 20: 6:7

33. Sun B, Liu R, Xiao ZD, Zhu X. c-MET protects breast cancer cells from apoptosis induced by sodium butyrate. PLoS One. 2012; 7: e30143.

34. William L. Farrar. Cancer Stem Cell. Cambridge University press. 2010; 50-51.

35. Charafe-Jauffret E, Ginestier C, Iovino F, Tarpin C, Diebel M, Esterni B, Houvenaeghel G, Extra JM, Bertucci F, Jacquemier J, Xerri L, Dontu G, Stassi G, et al.ALDH1positive cancer stem cells mediate metastasis and poor clinical outcome in inflammatory breast cancer. Clin Cancer Res. 2010; 16: 45-55.

36. Raha D, Wilson TR, Peng J, Peterson D, Yue P, Evangelista M, Wilson C, Merchant M, Settleman J. The Cancer Stem Cell Marker Aldehyde Dehydrogenase Is Required to Maintain a Drug-Tolerant Tumor Cell. Cancer Res. 2014; 74: 3579-3590.

37. Nishikawa S, Konno M, Hamabe A, Hasegawa S, Kano Y, Ohta K, Fukusumi T, Sakai D, Kudo T, Haraguchi N, Satoh $\mathrm{T}$, Takiguchi S, Mori M, et al. Aldehyde dehydrogenase high gastric cancer stem cells are resistant to chemotherapy. Int J Oncol. 2013; 42: 1437-1442.

38. Croker AK, Allan AL. Inhibition of aldehyde dehydrogenase (ALDH) activity reduces chemotherapy and radiation resistance of stem-like ALDHhiCD44+ human breast cancer cells. Breast Cancer Res Treat. 2012; 133: 75-87.

39. Tanei T, Morimoto K, Shimazu K, Kim SJ, Tanji Y, Taguchi T, Tamaki Y, Noguchi S. Association of Breast Cancer Stem Cells Identified by Aldehyde Dehydrogenase 1 Expression with Resistance to Sequential Paclitaxel and EpirubicinBased Chemotherapy for Breast Cancers. Clin Cancer Res. 2009; 15: 4234-4241.

40. Singh S, Brocker C, Koppaka V, Chen Y, Jackson BC, Matsumoto A, Thompson DC, Vasiliou V. Aldehyde Dehydrogenases in Cellular Responses to Oxidative/ electrophilic Stress. Free Radic Biol Med. 2013; 56: 89101.

41. Munshi N, Jeay S, Li Y, Chen CR, France DS, Ashwell MA, Hill J, Moussa MM, Leggett DS, Li CJ. ARQ 197, a Novel and Selective Inhibitor of the Human c-Met Receptor Tyrosine Kinase with Antitumor Activity. Mol Cancer Ther. 2010; 9: 1544-1553.

42. Eathiraj S, Palma R, Volckova E, Hirschi M, France DS, Ashwell MA, Chan TC. Discovery of a novel mode of protein kinase inhibition characterized by the mechanism of inhibition of human mesenchymal-epithelial transition factor (c-Met) protein autophosphorylation by ARQ197. J. Biol. Chem. 2011; 286: 20666-20676.

43. Tiedt R, Degenkolbe E, Furet P, Appleton BA, Wagner S, Schoepfer J, Buck E, Ruddy DA, Monahan JE, Jones MD, Blank J, Haasen D, Drueckes P, et al. A drug resistance screen using a selective MET inhibitor reveals a spectrum of mutations that partially overlap with activating mutations found in cancer patients. Cancer Res. 2011; 71: 5255-5264.

44. Schroeder GM, An Y, Cai ZW, Chen XT, Clark C, Cornelius LA, Dai J, Gullo-Brown J, Gupta A, Henley B, Hunt JT, Jeyaseelan R, Kamath A, et al. Discovery of N-(4-(2-amino3-chloropyridin-4-yloxy)-3-fluorophenyl)-4-ethoxy-1-(4fluorophenyl)-2-oxo-1,2-dihydropyridine-3-carboxamide (BMS-777607), a selective and orally efficacious inhibitor of the Met kinase superfamily. J Med Chem. 2009; 52: 1251-1254.

45. Brian K. Albrecht, Jean-Christophe Harmange, David Bauer, Loren Berry, Christiane Bode, Alessandro A. Boezio, April Chen, Deborah Choquette, Isabelle Dussault, Cary Fridrich, Satoko Hirai, Doug Hoffman, Jay F. Larrow, et al. Discovery and Optimization of Triazolopyridazines as Potent and Selective Inhibitors of the c-Met Kinase. J. Med. Chem. 2008; 51: 2879-2882

46. Katayama R, Kobayashi Y, Friboulet L, Lockerman EL, Koike S, Shaw AT, Engelman JA, Fujita N. Cabozantinib overcomes crizotinib resistance in ROS1 fusion positive cancer. Clin Cancer Res. 2015; 21: 166-174.

47. Liu L, Greger J, Shi H, Liu Y, Greshock J, Annan R, Halsey W, Sathe GM, Martin AM, Gilmer TM. Novel mechanism of Lapatinib resistance in HER2-positive breast tumor cells: activation of AXL. Cancer Res. 2009; 69: 6871-6878.

48. Qian F, Engst S, Yamaguchi K, Yu P, Won KA, Mock L, Lou T, Tan J, Li C, Tam D, Lougheed J, Yakes FM, Bentzien F, et al. Inhibition of tumor cell growth, invasion, and metastasis by EXEL-2880 (XL880, GSK1363089), a novel inhibitor of HGF and VEGF receptor tyrosine kinases. Cancer Res. 2009; 69: 8009-8016.

49. Cui JJ, McTigue M, Nambu M, Tran-Dubé M, Pairish M, Shen H, Jia L, Cheng H, Hoffman J, Le P, Jalaie M, Goetz $\mathrm{GH}$, Ryan K, et al. Discovery of a novel class of exquisitely selective mesenchymal-epithelial transition factor (c-MET) protein kinase inhibitors and identification of the clinical candidate 2-(4-(1-(quinolin-6-ylmethyl)-1H-[1,2,3] triazolo[4,5-b]pyrazin-6-yl)-1H-pyrazol-1-yl)ethanol (PF04217903) for the treatment of cancer. J Med Chem. 2012; 55: 8091-8109.

50. Zou HY, Li Q, Lee JH, Arango ME, Burgess K, Qiu M, Engstrom LD, Yamazaki S, Parker M, Timofeevski S, Cui JJ, McTigue M, Los G, et al. Sensitivity of Selected Human Tumor Models to PF-04217903, a Novel Selective c-Met Kinase Inhibitor. Mol Cancer Ther. 2012; 11: 1036-1047.

51. Zou HY, Li Q, Lee JH, Arango ME, McDonnell SR, Yamazaki S, Koudriakova TB, Alton G, Cui JJ, Kung PP, Nambu MD, Los G, Bender SL, et al. An orally available small-molecule inhibitor of c-Met, PF-2341066, exhibits cytoreductive antitumor efficacy through antiproliferative and antiangiogenic mechanisms. Cancer Res. 2007; 67: 4408-4417.

52. Christensen JG, Zou HY, Arango ME, Li Q, Lee JH, McDonnell SR, Yamazaki S, Alton GR, Mroczkowski B, Los G. Cytoreductive antitumor activity of PF-2341066, a 
novel inhibitor of anaplastic lymphoma kinase and c-Met, in experimental models of anaplastic large-cell lymphoma. Mol Cancer Ther. 2007; 6: 3314-3322.

53. Christensen JG, Schreck R, Burrows J, Kuruganti P, Chan E, Le P, Chen J, Wang X, Ruslim L, Blake R, Lipson KE, Ramphal J, Do S, et al. A Selective Small Molecule Inhibitor of c-Met Kinase Inhibits c-Met-Dependent Phenotypes in Vitro and Exhibits Cytoreductive Antitumor Activity in Vivo. Cancer Res. 2003; 63: 7345-7355.

54. Smolen GA, Sordella R, Muir B, Mohapatra G, Barmettler A, Archibald H, Kim WJ, Okimoto RA, Bell DW, Sgroi DC, Christensen JG, Settleman J, Haber DA. Amplification of MET may identify a subset of cancers with extreme sensitivity to the selective tyrosine kinase inhibitor PHA665752. PNAS. 2006; 103: 2316-2321. 